\title{
REVIEW
}

\section{THE INFLUENCE OF THE HUMAN GENOME ON CHRONIC VIRAL HEPATITIS OUTCOME}

\author{
Dahir Ramos de ANDRADE JÚNIOR \& Dahir Ramos de ANDRADE
}

\begin{abstract}
SUMMARY
The mechanisms that determine viral clearance or viral persistence in chronic viral hepatitis have yet to be identified. Recent advances in molecular genetics have permitted the detection of variations in immune response, often associated with polymorphism in the human genome. Differences in host susceptibility to infectious disease and disease severity cannot be attributed solely to the virulence of microbial agents. Several recent advances concerning the influence of human genes in chronic viral hepatitis B and C are discussed in this article: a) the associations between human leukocyte antigen polymorphism and viral hepatic disease susceptibility or resistance; b) protective alleles influencing hepatitis B virus (HBV) and hepatitis $\mathrm{C}$ virus (HCV) evolution; c) prejudicial alleles influencing $\mathrm{HBV}$ and $\mathrm{HCV}$; d) candidate genes associated with HBV and HCV evolution; d) other genetic factors that may contribute to chronic hepatitis $\mathrm{C}$ evolution (genes influencing hepatic stellate cells, TGF- $\beta 1$ and TNF-alpha production, hepatic iron deposits and angiotensin II production, among others). Recent discoveries regarding genetic associations with chronic viral hepatitis may provide clues to understanding the development of end-stage complications such as cirrhosis or hepatocellular carcinoma. In the near future, analysis of the human genome will allow the elucidation of both the natural course of viral hepatitis and its response to therapy.
\end{abstract}

KEYWORDS: Chronic viral hepatitis; Human genes; HLA antigens.

\section{INTRODUCTION}

Progress has been made in the tools used in the field of molecular genetics. This greater knowledge has made it possible to detect immune response variations, which are often associated with polymorphism in the human genome, as well as facilitating the determination of correlation between such polymorphism and disease mechanisms. The clinical outcome of an infectious disease may be predetermined by genetic polymorphism. Thus, differences in host susceptibility to infectious disease and disease severity cannot be attributed solely to the virulence of the microbial pathogen. Major histocompatibility complex (MHC) gene products are vital in regulating several antiviral immune reactions. In addition, genetic factors controlling the host immune response could play an important role in determining infection outcome. Alloantigen stimulation of the immune system requires that antigen-presenting cells present antigens to antigen-specific $\mathrm{T}$ lymphocytes, a phase that is dependent upon MHC compatibility. Alloantigens are taken up by antigen-presenting cells, which process them and reexpress the antigens on the cell surface, along with human leukocyte antigens (HLAs) to be recognized by the T-cell receptor. The various HLA class II molecules can differ by only a single amino acid, thus modifying their peptidebinding ability. This can cause significant changes in the presentation of the antigen to the $\mathrm{T}$ cell receptor, which in turn affects immune response ${ }^{54,59}$.

Associations between HLA polymorphism and disease susceptibility as well as disease resistance have been well investigated, especially in autoimmune and metabolic diseases ${ }^{22,27}$. Moreover, correlations between HLA polymorphism and clinical outcome for some viral infections have been reported ${ }^{63}$. The mechanisms that determine clearance or viral persistence in chronic viral hepatitis have not yet been identified. So far, little is known about the potential role of host factors in chronic hepatitis $\mathrm{C}$ virus (HCV) infection, or on the genetics of the immune response. Genetic associations may also provide clues to the development of endstage complications such as cirrhosis or hepatocellular carcinoma. In the near future, analysis of the human genome will allow researchers to clarify the natural outcome of viral hepatitis and better determine its response to therapy.

\section{HEPATITIS AND THE HUMAN GENOME}

2.1. Candidate Genes and Microsatellites: The genes that encode products suspected of influencing the susceptibility or outcome of a disease are called candidate genes. Within this group, there are genes

Financial Support: Fundação de Amparo à Pesquisa do Estado de São Paulo (FAPESP)

Study conducted at: Laboratory of Medical Investigation/LIM-54, University of São Paulo, School of Medicine, São Paulo, SP, Brazil

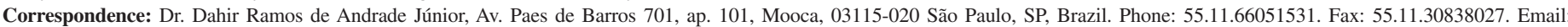
dahira@uol.com.br 
that encode the chemokine receptor 5 (CCR5), which serves as a coreceptor for the entry of human immunodeficiency virus (HIV) into CD4 cells $^{19}$, the NRAMP1 gene (involved in host susceptibility to Mycobacterium tuberculosis infection) $)^{12,13}$, and the hemochromatosis gene HFE (iron has been implicated in the viral hepatitis pathogenesis) ${ }^{14}$, among others. One of the procedures used to identify a candidate gene is the genome-wide scan, which uses densely distributed microsatellite or single nucleotide polymorphism (SNP) markers to identify areas of interest in the genome. Distortions in the frequencies of these markers have been compared between one group of patients presenting positive results and another group showing no positive results, as well as within families presenting a disease phenotype ${ }^{20}$. If a specific disease has been correlated with a marker, this marker will be found significantly more often in those patients presenting the disease.

Microsatellite markers are tandem repeats of two to four base pairs (bp), occurring approximately every 30 kilobases in the eukaryotic genome. In a study involving several diseases with known HLA associations, such as diabetes mellitus, narcolepsy, uveitis, C2 deficiency and multiple sclerosis, significant correlations were found between these diseases and the presence of microsatellites markers in proximity to the disease gene ${ }^{15}$. Since they do not mutate as frequently, are more abundant and are easier to analyze, SNPs (polymorphisms produced by a single base change) may be superior to microsatellites. Denaturing highperformance liquid chromatography or PCR methods may be used to identify SNPs within the genome ${ }^{28,65}$.

2.2. HLA molecules and the Major Histocompatibility Complex $(\boldsymbol{M H C})$ : The HLA complex consists of class I (HLA-A, -B, and -C) and class II (HLA-DRB1, -DQA1, -DQB1, -DPA1, and-DPB1) alleles, which are glycoproteins situated on the cellular surface and encoded by MHC genes. Class I HLA molecules consist of a heavy $45-\mathrm{kDa}$ chain and a $15-\mathrm{kDa} \beta 2$ microglobulin chain. Class II HLA molecules are heterodimeric and consist of alpha and beta chains of approximately 30$\mathrm{kDa}$ each. There are over 1000 different alleles that encode HLA class I and class II molecules ${ }^{1}$. As primary step of immune response, HLAs present antigens to both CD4+ helper T cells and CD8+ cytolytic T cells (CTLs).

The MHC complex is located on the short arm of chromosome 6 and encodes several protein products involved in the immune response, such as protein complement and TNF- $\alpha$. Class I HLA molecules generally present antigens that are generated endogenously, including epitopes from viruses and other intracellular pathogens. In order to kill the infected cell, CTLs must recognize the combination of viral epitope and class I antigen coexpressed on the surface of hepatocytes. Class II HLA molecules occur on antigen presenting cells (APCs) or dendritic cells that present extracellularly derived antigens (including viral peptides) to CD4+ T cells in order to stimulate cytokine release, thereby generating humoral and cell-mediated immune responses. In acute HCV infection, early host immune response is one of the determinants of viral persistence. Class I HLAs, which present foreign antigens to CTLs, are integral components of this response.

The HLA genes are the most diverse in the human genome, probably due to an evolutionary adaptation to immune pressure from various infectious agents. The serological typing of class I HLA molecules is based on HLA-specific antibody binding to antigens on the cell surface.
Thus, polymorphisms in the unexposed peptide-binding groove, which determines the antigenic epitopes presented to T cells, often escape detection. At present, the most accurate methods for the typing of class I HLAs involve combinations of PCR-SSP (polymerase chain reaction sequence-specific primer), PCR-SSO (polymerase chain reaction sequence-specific oligonucleotide), and direct sequencing ${ }^{11,12}$.

2.3. Candidate Gene Analysis: Linkage disequilibrium refers to the non random association of alleles that causes a particular allelic combination to occur more frequently than would be expected by chance. For example, HLA-A1 and HLA-B8 occur in $27.5 \%$ and $15.7 \%$ of Caucasians, although they would be expected to occur concomitantly only in $4.3 \%{ }^{67}$. This is due to the fact that HLA-A1 and HLA-B8 are in linkage disequilibrium and form a haplotype ${ }^{75}$. Linkage disequilibrium can occur as a consequence of genetic proximity or can result from selection pressure that favors a particular combination of alleles even at two distant loci.

Family studies can be used to provide clues to genetic susceptibility to infectious disease. In these studies, individuals presenting a particular disease comprise the initial group and their relatives are analyzed to determine whether they also have increased susceptibility to the same disease. By means of current molecular genetics technology, results from disease association studies can be combined with family studies to determine the inheritance pattern of a particular candidate gene.

Candidate gene polymorphism can be studied in a group of individuals exposed to a particular infection. Most studies of HBV and HCV have employed this particular method. However, these studies have had some limitations related to inappropriate control groups and low numbers of participants s,18,33,66. $^{4}$.

Genetic epidemiological studies require large cohorts in order to attain adequate statistical power. Studies that are HLA related also require great numbers of individuals and regular distribution of alleles at some of these loci. For example, for an allele with a frequency of 10\%, 307 case-control pairs are needed to achieve an $80 \%$ chance of detecting a two-fold disease correlation ${ }^{67}$.

Allele frequencies vary among ethnic groups, and many correlations may only be detected in people of a particular ethnicity. A good example is the CCR5 32-bp deletion polymorphism for HIV, which is found in Caucasians but not in blacks ${ }^{49}$.

\subsection{Human Genes and $\mathrm{HBV}$}

2.4.1. HBV and Protective Alleles: In economically developed countries $\mathrm{HBV}$ is acquired in adulthood through sexual contact or intravenous drug use, and chronic infection occurs in $5 \%$ to $10 \%$ of $\operatorname{cases}^{25,44}$. In developing countries, where endemic levels of HBV are high, acquisition usually occurs in childhood from either perinatal or horizontal transmission.

Family studies in China have provided evidence that host genetic factors may influence viral persistence. It has been shown that concordance rates for $\mathrm{AgHBe}$ persistence were higher between identical twins than between fraternal twins ${ }^{46}$. However, few family studies have examined the genetic basis for susceptibility to HBV infection. 
Most genetic studies involving HBV susceptibility have focused on its correlations with HLA I and HLA II $^{53,78}$. In general, such studies have used controls taken from the population at large, although there have been seven studies that used controls that had previously been infected with HBV and in whom the HBV infection had been resolved $^{4,33,66,72,77,78,85}$. None of the seven studies found a correlation between class I alleles and viral persistence. In four of the seven studies that compared viral persistence with viral clearance, correlations with HLA class II alleles were noted ${ }^{4,33,66,72}$.

THURSZ et al. studied both children and adults in Gambia, and found that the MHC class II allele HLA-DRB1*1302 was more frequent in individuals that had cleared the infection than in those presenting persistent infection ${ }^{72}$. The HLA-DRB $1 * 1302$ allele is also associated with a reduced risk of severe malaria in Gambian children. Malaria and $\mathrm{HBV}$ are both leading causes of premature death in West Africa. It is possible that, in Gambians, there is a selective advantage for the DRB1*1302 allele associated with both diseases ${ }^{72}$. A German study examined the effect of DRB1*1302 in adults and also suggested that this allele is protective against viral persistence ${ }^{33}$. In a study of Caucasian subjects, a single class I allele (HLA-A*0301) was associated with HBV clearance with an odds ratio (OR) of $0.47^{70}$.

A study of Qatari adults showed different correlations between HLA class II alleles and HBV infection, and the results indicated that HLADR2 was a protective factor $^{3}$. Another study showed that HLA-DR6 and HLA-DR13 were correlated with HBV clearance in Koreans ${ }^{2}$.

DOHERTY \& ZINKERNAGEL ${ }^{21}$ anticipated that heterozygosity at MHC loci could be advantageous for viral clearance since heterozygotes have twice as many alleles with which to present antigens than do homozygotes. A heterozygote for three class I loci (HLA-A, -B, and $\mathrm{C})$, has six different alleles with which to present antigens, whereas a homozygote has only three. Therefore, HIV-infected individuals who are heterozygotes for HLA class I alleles are less likely to progress rapidly to acquired immunodeficiency syndrome (AIDS) ${ }^{16}$.

Finally, the only reproducible correlation between host genes and $\mathrm{HBV}$ infection involves HLA class II alleles. If specific alleles of the class II loci are efficient for viral clearance or for slowing disease progression, then it follows that a CD4+ helper T cell response would be implicated as a critical factor in viral clearance. On the other hand, HLA class I correlations would suggest that a CD8+ CTL response is also a critical factor in eliminating HBV.

2.4.2. HBV Infection and Prejudicial Alleles: In a study involving 91 African-American adults who were regular intravenous drug users, 31 presenting self-limited HBV infections and 60 with persistent HBV infections, HBV persistence was shown to correlate with the DQA $1 * 0501$ and DQB1*0301 alleles found in a common DQA1-DQB1 haplotype ${ }^{66}$. The authors also found that the three loci of the DQA1*0501DQB1*0301-DRB1*1102 haplotype were significantly correlated with viral persistence ${ }^{66}$. In another study, HLA-DRB $1 * 0301$, HLADQA $1 * 0501$ and HLA-DQB $1 * 0301$ were found to be closely correlated with susceptibility to chronic hepatitis B, whereas HLA-DRB1*1101/ 1104 and HLA-DQA $1 * 0301$ were correlated with resistance to chronic hepatitis $\mathrm{B}^{37}$.
The HLA-B*08 allele has been associated with B virus persistence both independently $(\mathrm{OR}, 1.59)$ and as part of the conserved Caucasian haplotype $\mathrm{A} * 01-\mathrm{B} * 08-\mathrm{DRB} 1 * 03$. The $\mathrm{B} * 44-\mathrm{CW}^{*} 1601(\mathrm{OR}, 2.23)$ and $\mathrm{B} * 44-\mathrm{Cw}^{*} 0501(\mathrm{OR}, 1.99)$ haplotypes have also been associated with viral persistence ${ }^{70}$. The HLA-DR7 allele was also found to be a risk factor for hepatitis B in another study ${ }^{3}$. Further investigations have demonstrated that HLA-DR9 was significantly more frequent in chronic HBV carriers ${ }^{2}$.

2.4.3. Other Candidate Genes Associated with HBV: Genes that encode tumor necrosis factor-alpha (TNF- $\alpha$ ), as well as mannose binding protein (MBP), and vitamin D receptor have been studied as potential candidate genes, due to the role they may play in HBV pathogenesis. Patients infected with HBV have increased levels of TNF- $\alpha$ and upregulation of TNF- $\alpha$ receptors $^{61}$. In addition, CTL secretion of TNF$\alpha$ was able to stop HBV gene expression in transgenic mice infected with $\mathrm{HBV}^{29}$. It is possible that polymorphisms in the TNF- $\alpha$ gene may influence HBV persistence. The TNF- $\alpha$ gene is located within the MHC HLA class III region, and two polymorphism in its promoter region (creating a biallelic polymorphism) at positions -308 and -238 alter TNF$\alpha$ expression. The -238 promoter variant was significantly correlated with $\mathrm{HBV}$ persistence in a cohort of 71 chronically and 32 transiently HBV infected German patients ${ }^{29,35,81}$.

Mutations in the mannose binding protein (MBP) gene (codons 52, 54 and 57), as well as in its promoter lead to low serum concentrations of MBP, preventing both its ability to activate complement and to act as an opsonin ${ }^{64}$. The HBV envelope has a mannose-rich oligosaccharide to which MBP could bind. Therefore, these mutations may be important in HBV pathogenesis ${ }^{71}$. The mutation of codon 52 in the MBP gene has been correlated with persistent HBV infection in British Caucasians but not in Chinese Asians ${ }^{71}$.

The active form of vitamin $\mathrm{D}$, in addition to its role in calcium regulation, is an immunomodulatory hormone that inhibits Th1 response and activates Th2 response. The vitamin D receptor gene has two known genetic polymorphisms that have been associated with several diseases such as tuberculosis, leprosy and AIDS $^{47}$. The tt genotype in one polymorphism of vitamin D receptor gene was associated with HBV clearance in another study ${ }^{13}$.

\subsection{Human Genes and $\mathrm{HCV}$}

2.5.1. HCV and Protective Alleles: The HCV pathogen infects individuals by the parenteral route ${ }^{6}$, and $75 \%$ to $85 \%$ of $\mathrm{HCV}$ infections become persistent. The HCV antibody persists for years after $\mathrm{HCV}$ infection, even in those individuals who present self-limited infections. The presence of HCV RNA (detected by PCR) is used to differentiate viral clearance from persistence. Viremia can be intermittent in the first year of infection, and the presence of HCV RNA should be considered when attempting to determine the outcome of an acute $\mathrm{HCV}$ infection ${ }^{79}$.

Genetic studies have examined four aspects of HCV infection: 1) $\mathrm{HCV}$ clearance; 2) HCV evolution to cirrhosis; 3) susceptibility to HCV infection; 4) $\mathrm{HCV}$ persistence.

Viral clearance may be defined as one positive anti-HCV test and two negative viral RNA tests at least six months apart. Persistence is 
defined as continued HCV RNA positivity over a one-year period. In addition, the degree of liver damage can be semiquantitatively assessed by a system used to score liver biopsies ${ }^{40}$. Three studies have shown that HCV clearance is associated with the DQB $1 * 0301$ allele $5,18,52$ and that the DRB1*04 and DQA1*03 alleles are protective in strong linkage disequilibrium with DQB $1 * 0301^{18}$. The DRB $1 * 1101$ allele is also in linkage disequilibrium with DQB $1 * 0301$, and has been correlated with HCV clearance ${ }^{5}$ A similar correlation has been found between the DRB1*11 allele and HCV clearance ${ }^{52}$. In a study with an ethnically diverse cohort, a weak correlation was found between HLA-DQB1*0301 and viral clearance in the combined ethnic groups (OR, 0.72), in contrast to the stronger correlation found in black subjects. In Caucasian subjects, viral clearance was correlated with DRB $1 * 0101(\mathrm{OR}, 0.32)$ and its DQB $1 * 0501$ haplotype ${ }^{68}$. In a study of patients with HCV infection, YOSHIZAWA et al. ${ }^{84}$ showed higher frequency of DRB1*12 $(* 1201$ and *1202), DQB $1 * 0301$ and DRB3*03 alleles in asymptomatic carrier state (ACS) patients than in those with liver cirrhosis (LC) (OR, 11.23; $\mathrm{OR}, 4.25$; and $\mathrm{OR}, 3.22$ respectively). The authors also showed that the DQB $1 * 0503$ frequency was lower in ACS patients than in LC patients (OR, 0.05). In another study, the HLA haplotype DRB $1 * 1104$ / DQB1*0301 appears to have contributed to the spontaneous clearance of HCV infection ${ }^{48}$.

Two Japanese studies drew comparisons between HCV carriers with normal liver function tests and normal hepatic histology, and HCV patients with elevated liver enzymes and cirrhosis ${ }^{3,43}$. In these two studies, no less than five HLA class II alleles were suggested as being protective against $\mathrm{HCV}$ disease progression. Of the five alleles, only DRB $1 * 1302$ has been shown to have the same tendency for protection in another study $^{42}$. The DRB $1 * 1101$ allele has been correlated with viral clearance, as well as with slower disease progression ${ }^{5,42}$.

PEANO et al. ${ }^{54}$ found an inverse correlation between frequency of the HLA-DR5 antigen and the severity of liver disease. Several studies have found class I and class II alleles to be correlated with HCV infection ${ }^{17,31,32,73,78}$. In another work, it was shown that the DQA1*03 and DQB $1 * 0302$ alleles promote viral clearance and confer protection against chronic HCV infection in Caucasians ${ }^{73}$. HOHLER et al. showed that frequency of the DRB $1 * 1302$ allele is lower in $\mathrm{HCV}$-infected individuals than in controls ${ }^{32}$. This allele has been previously correlated with slower disease progression ${ }^{42}$.

Two other recent studies identified additional haplotypes that correlate with HCV clearance: in one of these, $25 \mathrm{RNA}-\mathrm{HCV}$ negative subjects were compared with 103 RNA-HCV positive subjects in France, and the DRB1*1101, DQA1*0501 and DQB1*0301 alleles were found to be correlated with viral clearance 5 . In the other study, 49 RNA-HCV negative subjects were compared with 55 RNA-HCV positive subjects in Great Britain, and the DRB $1 * 0401$, DQA $1 * 03$ and DQB $1 * 0301$ alleles were also found to be correlated with viral clearance ${ }^{18}$. The DQB $1 * 0301$ allele was the only one the two haplotypes had in common, suggesting that this allele is important for HCV clearance.

The HLA class II allele, DRB1*11, was found at a reduced frequency in 49 patients with chronic hepatitis $\mathrm{C}$ (anti-HCV and HCV RNA positive) compared to controls $(22.4$ versus $51.0 \%$; $<<0.01$, OR $=0.3)$. The authors state that there is a possibility that HLA-DRB $1 * 11$ contains a protective feature in chronic $\mathrm{HCV}$ infection, hence this allele may also be correlated with protection against $\mathrm{HCV}$ infection ${ }^{83}$. In addition, patients with cirrhosis presented a lower DRB $1 * 11$ allele frequency $(5.6 \%$ vs. $14.5 \%$ ) in another study ${ }^{36}$. TILLMANN et al. ${ }^{74}$ showed that the presence of HLA-DRB $1 * 11$ and HLA-DQB $1 * 03$ alleles were associated with a reduced risk for the development of $\mathrm{HCV}$-induced end-stage liver disease.

An additional study showed a high frequency of DRB1*1104 and DQB $1 * 0301$ alleles in asymptomatic patients ${ }^{48}$. The DQB $1 * 0301$ and DRB $1 * 0401$ alleles were frequently found in Irish patients presenting viral clearance ${ }^{50}$.

To date, research into the association between HLA and spontaneous HCV clearance has indicated that DR4, DR11 and/or DQB $1 * 0301$ alleles are associated with viral clearance in European individuals ${ }^{3}$. In relation to the role of $\mathrm{DQB} 1 * 0301$ allele in $\mathrm{HCV}$ clearance, a more rigorous analysis of the other class II and class I alleles is essential in order to determine whether this allele is simply an adjunct to the actual protective allele at another HLA locus. Further studies involving HLA alleles are necessary to determine the exact correlation with $\mathrm{HCV}$ clearance.

After several investigations into accidents involving contaminated anti-D immunoglobulin performed in an Irish population, a better understanding of the role of MHC class II alleles in $\mathrm{HCV}$ has been gained $^{9,23,24,39,56,57}$. Administration of contaminated anti-D immunoglobulin resulted in the iatrogenic HCV genotype 1b infection of 156 Irish women between May 1977 and November 1978. The contaminated anti-D immunoglobulin was derived from a single infected donor, and the study population was homogeneous in terms of gender, source of infection, and ethnicity. In this group of studies, FANNING et $a l{ }^{23,24}$ suggested that the HLA DRB $1 * 01$ allele contributed to the spontaneous resolution of a primary $\mathrm{HCV}$ infection in this population. No correlations with either viral clearance or persistence were found at the DQB1 locus. McKIERNAN et al. ${ }^{51}$ examined the correlation between MHC and HCV infection status. The DRB1*0101 and DQB1*0501 alleles were more frequent in subjects who had achieved viral clearance than in chronically infected subjects $(32.3 \%$ and $36.8 \%$ versus $8.8 \%$ and $14.2 \%$, respectively; $\mathrm{p}=0.002$ ). Both DRB1* 03011 and DQB1* 0201 alleles were significantly less frequent in subjects presenting higher inflammatory scores in liver biopsies.

THIO et al. ${ }^{69}$ showed that HLA-A*1101 (OR, 0.49), HLA-B*57 $(\mathrm{OR}, 0.62)$ and $\mathrm{HLA}-\mathrm{Cw}^{*} 0102(\mathrm{OR}, 0.43)$ were correlated with viral clearance. In a study of $21 \mathrm{German}$ patients presenting self-limited HCV infection, a higher frequency of the HLA-DR15 (B1*15011) allele was observed in these patients than in patients with chronic hepatitis $\mathrm{C}^{44}$. These data suggest that HLA-DR15 (B1*15011) might represent an important genetic factor for the elimination of $\mathrm{HCV}$ in Germany.

2.5.2. HCV Infections and Prejudicial Alleles: The allele DRB1*0301 (OR, 2.36) and its DQB1*0201 haplotype have been found to be correlated with $\mathrm{HCV}$ persistence ${ }^{68}$. The predominance of the DQB $1 * 0502$ allele in cirrhotic patients with rapid disease progression may indicate an influence of this allele on the progression of the HCVrelated liver disease ${ }^{48}$.

In the two previously cited Japanese studies ${ }^{3,43}$, DQB $1 * 0401$, DRB1*0405 alleles were more frequent in individuals who developed 
chronic HCV disease. In one of these studies, subjects with three-loci haplotype HLA-B54-DQB1*0401-DRB1*0405 showed 13.2 times more liver injury than those with the two-loci haplotype DQB1*0401DRB $1 * 0405$ (minus HLA-B54) ${ }^{43}$. In Japanese patients, the DR4 and DQB1*0401 alleles were more frequent in HCV-infected individuals than in controls ${ }^{31}$. Additionally, both of these alleles were associated with a more rapid progression of HCV infection ${ }^{3}$.

One study showed that DRB $1 * 03$ and DQB $1 * 0201$ allele frequencies appear to be higher in patients with $\mathrm{HCV}$ and cirrhosis ${ }^{36}$. The same authors also found the mean index of fibrosis to be higher in DR3-positive patients than in DR11-positive patients $(2.14 \text { vs. } 1.58 ; \mathrm{p}=0.05)^{36}$. Similarly, DRB $1 * 0405$ and DQB1*0401 alleles have been associated with more severe disease in patients presenting cirrhosis ${ }^{3}$. In chronic hepatitis $\mathrm{C}$ patients, a strong correlation between the HLA DRB $1 * 11$ allele and persistence of normal ALT has been shown ${ }^{60}$.

Some studies have shown that the presence of DRB $1 * 0701$ in the absence of DQB $1 * 0501$ may constitute influence of this allele in the persistence of $\mathrm{HCV}$ infection ${ }^{23,24}$. In another study, DRB1*03011 and DQB1*0201 alleles occurred more frequently in chronically infected subjects than in those who had cleared the virus ${ }^{51}$.

It has also been shown that HLA-A*2301 (OR, 1.78) and HLA$\mathrm{Cw}^{*} 04(\mathrm{OR}, 1.78)$ correlate with $\mathrm{HCV}$ persistence ${ }^{69}$. In that study, HLA$\mathrm{CW}^{*} 04$ was reported to be in strong linkage disequilibrium with HLA$\mathrm{B} * 53$ and HLA-B*35, and only the $\mathrm{Cw} * 04-\mathrm{B} * 53$ haplotype (OR, 1.76) correlated (albeit weakly) with viral persistence. Those authors also found that, among persistently infected individuals, the HLA-Cw*04 allele was correlated with HCV persistence, but not with HCV RNA levels. According to the authors, since $\mathrm{CW}^{*} 04$ is a ligand for the killer immunoglobulin-like receptors on natural killer cells, these cells may be involved in recovery from HCV infection. They conclude that further investigation is needed in order to understand the relationship between class I alleles and HCV clearance ${ }^{69}$.

2.5.3. Other Candidate Genes Associated with HCV: Two other candidate genes that have been studied in association with $\mathrm{HCV}$ persistence are TNF- $\alpha$ and the hemochromatosis gene (HFE). Mutations in the TNF$\alpha$ gene have been suggested as candidate genes, because TNF- $\alpha$ levels are elevated in HCV infection, probably due to CTL production in the liver ${ }^{41}$. In a study of 82 persistent $\mathrm{HCV}$ infection patients and 99 controls, the $238 \mathrm{~A}$ TNF- $\alpha$ promoter variant was significantly correlated with persistent infection $^{34}$. In addition to playing a major role as mediator of the inflammatory response, TNF- $\alpha$ downregulates collagen synthesis and may promote apoptosis of either inflammatory or fibrogenic cells ${ }^{8}$.

The HFE gene has been studied in HCV infection due to the potential effect of iron on $\mathrm{HCV}$ pathogenesis. Iron may promote $\mathrm{HCV}$ replication, increase oxidative stress and impair host immunity ${ }^{17}$. Situated on chromosome 6p, telomeric to the HLA-A complex, HFE is a MHC classI-like gene. This gene presents two identified mutations: the first at amino acid position $282(\mathrm{C} 282 \mathrm{Y})$, and the second at amino acid position 63 (H63D). The protein encoded by the HFE gene may directly limit the amount of iron absorbed in the small intestine, or may regulate gene products that control iron absorption. As a whole these mutations lead to increased iron absorption ${ }^{25}$. Some authors have investigated the role of these mutations in individuals with chronic HCV infection and found that the frequency of heterozygosity for the C282Y mutation in HCVinfected patients with chronic active hepatitis is comparable to that found in the general population ${ }^{30}$. Comparisons between chronically HCV infected patients and random controls have revealed no differences in the frequency of either mutation ${ }^{38}$. Another study involving chronic $\mathrm{HCV}$ hepatitis patients has shown that individuals who are heterozygous for the C282 mutation present a higher degree of fibrosis but only minor increases in iron stores ${ }^{62}$. Overall, these data led us to conclude that the HFE mutations contribute to, but do not fully explain, iron accumulation in individuals with chronic HCV infection. Further studies are warranted in order to increase understanding of this aspect.

Progressive hepatic fibrosis and cirrhosis develop in $20 \%$ to $30 \%$ of patients with chronic hepatitis C. Although this phenomenon is linked to $\mathrm{HCV}$ presence, it does not occur through $\mathrm{HCV}$ influence alone but also depends on collagen production by Ito cells or hepatic stellate cells (HSCs). These HSCs are situated between the endothelial lining and the hepatocytes (Disse's space), a site consistent with their role in the recruitment of leukocytes and their targeting of damaged hepatocytes. During the inflammatory phenomenon that occurs in hepatitis C, Kupffer cells produce large quantities of secreted cytokines such as TNF- $\alpha$ and Interferon-gamma. Cytokine secretion into the hepatic microenvironment contributes to the activation of HSCs. The HSCs thus abandon their quiescent state and begin storing vitamin $\mathrm{D}$, as well as reaching an actively proliferating myofibroblast-like cell state. Furthermore, HSC activation is characterized by differential gene expression of connective tissue components, matrix degrading enzymes, and their inhibitors, resulting in matrix accumulation. Activated HSC produces several collagen types. Anti-inflammatory cytokines, such as interleukin-10 (IL-10), which presents prominent antifibrotic activity through downregulation of collagen 1 expression, are also produced by $\mathrm{HSCs}^{80}$.

These recent findings concerning the role of HSCs in hepatic fibrogenesis have produced notable consequences. More extensive research has been carried out regarding blockade and inhibition of HSCs and the resulting reduction in collagen production by these cells. In addition, enzymes such as collagenases and tissue inhibitors of metalloproteinases (TIMPs), as well as fibrogenic cytokines such as transforming growth factor-beta 1 (TGF- $\beta 1$ ) have been studied. Clearly, HSCs are involved at all stages of the hepatic wound healing process. There is evidence suggesting that HSCs initially participate in the recruitment of inflammatory cells and subsequently contribute to the reparative phase of wound healing through extracellular matrix production. In the near future, these findings regarding HSC biology and genetic control will be useful in order to improve the therapeutic armamentarium available for better treatment of hepatic diseases.

Activation of HSCs and HSC production of extracellular matrix proteins are both facilitated by the presence of TGF- $\beta 1$. Messenger RNA (mRNA) from TGF- $\beta 1$ is increased in the liver of patients presenting chronic HCV, and a correlation has been shown between TGF- $\beta 1$ mRNA expression and expression of type 1 collagen mRNA ${ }^{58}$.

Cytokine production capacity has a significant genetic component, which explains why there are differences between individuals in their ability to produce cytokines after in vitro stimulation of peripheral blood leukocytes. This has been attributed to polymorphisms within the regulatory regions of cytokine genes. For example, several polymorphic sites have 
been described within the TGF- $\beta 1$ gene, including two in the promoter region at -800 and $-507 \mathrm{bp}$ from the transcription start site, one at $72 \mathrm{bp}$, and two in the signal sequence at codons 10 and $25^{7}$. Another polymorphism has been identified in the promoter region of the IL-10 gene, which contains three biallelic polymorphisms at - 1082, -819 , and - $592 \mathrm{bp}$ from the transcription start site. These three biallelic polymorphisms produce haplotypes GCC, ACC and ATA, respectively ${ }^{75}$. Similarly the promoter region of the TNF- $\alpha$ gene contains a biallelic polymorphism at position $308 \mathrm{bp}$ from the transcription start site ${ }^{82}$. Although inheritance of the high TGF- $\beta 1$ producing genotype is associated with the development of fibrotic lung disease ${ }^{7}$, the role of these genetic polymorphisms in the progression of other fibrotic diseases is unclear.

The genetic variability in factors influencing fibrogenesis may account for some of the variability in disease progression seen in patients with chronic hepatitis C. In a study of 128 patients with chronic hepatitis $\mathrm{C}$, a statistically significant correlation was shown between inheritance of the genotypes for high production of TGF- $\beta 1$ or angiotensinogen (AT) and development of progressive hepatic fibrosis ${ }^{55}$. This suggests that the angiotensin II, the principal effector molecule of the reninangiotensin system and a potent vasoconstrictor, may mediate production of TBF- $\beta 1$, thereby influencing the hepatic extracellular matrix ${ }^{11}$. Cell culture studies have revealed that angiotensin II directly stimulates transcription and bioactivation of TGF- $\beta 1$ in several cell types: vascular smooth muscle cells, renal proximal tubular cells, mesangial cells, cardiac fibroblasts, and endothelial cells ${ }^{27}$.

Although there is currently no data confirming the existence of a local renin-angiotensin system exists within the hepatic microenvironment, the recent data concerning the presence of angiotensin receptors on $\mathrm{HSCs}^{10}$ suggest that this might be an important area for further research. Therefore, drugs that inhibit angiotensin II-mediated TGF- $\beta 1$ expression, such as ACE inhibitors and AII-receptor blockers might be used to reduce hepatic fibrosis.

\section{CONCLUSIONS}

Further genetic studies performed in patients with chronic viral hepatitis have contributed to the understanding of its pathogenesis. Various MHC alleles that are correlated with more favorable outcomes in cases of viral hepatitis have been identified in diverse populations. The DRB1*1302, A*0301, DR2, DR6 and DR13 alleles are correlated with better HBV outcomes, whereas DQB1*0301, DQB1*0201, DQB $1 * 03, \mathrm{DQA} 1 * 03, \mathrm{DRB} 1 * 01, \mathrm{DRB} 1 * 0101, \mathrm{DRB} 1 * 0301$, $\mathrm{DRB} 1 * 04, \mathrm{DRB} 1 * 0401, \mathrm{DRB} 1 * 11, \mathrm{DRB} 1 * 12, \mathrm{DRB} 1 * 1101$, DRB1*1104, DRB1*1302, DRB3*03, DRQ1*1101, DQA1*03, DQA1*0501, DQB1*0302, A*1101, B*57, Cw*0102, DR15 alleles are correlated with better HCV outcomes. On the other hand, some studies have shown correlation between specific alleles and less favorable clinical outcomes for $\mathrm{HBV}$ and $\mathrm{HCV}$ patients. Identifying correlation between specific genes and the evolution of viral hepatitis infection is the first step toward greater understanding of the pathogenesis of hepatitis. The next step will be finding correlations between these genes and immune response. These findings will be useful in the near future in order to develop appropriate therapeutic strategies for controlling viral hepatitis, as well as to improve current knowledge regarding hepatitis prognosis. Further studies involving different populations are necessary so that the specific genes present in $\mathrm{HBV}$ and $\mathrm{HCV}$ patients may be identified.

\section{RESUMO}

\section{A influência do genoma humano no curso das hepatites virais crônicas}

Os mecanismos que determinam o clearance ou a persistência da infecção viral nas hepatites virais crônicas não estão ainda bem identificados. O progresso no conhecimento sobre as ferramentas genéticas moleculares tem permitido detectar variações na resposta imune, que freqüentemente são associadas com polimorfismos do genoma humano. As diferenças na susceptibilidade do hospedeiro para as doenças infecciosas e a intensidade das doenças não podem ser atribuídas apenas à virulência do agente microbiano. Neste artigo são discutidos vários avanços recentes no conhecimento sobre a influência dos genes humanos nas hepatites crônicas B e C, a saber: a) As associações entre os polimorfismos HLA e a susceptibilidade ou resistência às doenças hepáticas virais; b) Alelos protetores influenciando as hepatites virais $\mathrm{B}$ (HVB) e C (HVC); c) Alelos prejudiciais influenciando HVB e HVC; d) Genes candidatos associados com a evolução clínica de HVB e HVC (genes que influenciam as células estreladas do fígado, a produção de TGF- $\beta 1$ e TNF- $\alpha$, os depósitos de ferro hepáticos, a produção de angiotensina II, entre outros). O conhecimento das associações genéticas com as hepatites virais crônicas pode fornecer indícios para o pleno entendimento de como se desenvolvem as suas complicações terminais, como a cirrose e o carcinoma hepatocelular. Em futuro próximo, a análise do genoma humano será capaz de elucidar o curso natural de uma hepatite viral, bem como a sua resposta à terapêutica.

\section{REFERENCES}

1. ABBAS, A.K.; LICHTMAN, A.H. \& POKER, J.S. - Cellular and molecular immunology. 3. ed. Philadelphia, W.B. Saunders, 1997.

2. AHN, S.H.; HAN, K.H.; PARK, J.Y. et al. - Association between hepatitis B virus infection and HLA-DR type in Korea. Hepatology, 31: 1371-1373, 2000.

3. AIKAWA, T.; KOJIMA, M.; ONISHI, H. et al. - HLA DRB1 and DQB1 alleles and haplotypes influencing the progression of hepatitis C. J. med. Virol., 49: 274-278, 1996.

4. ALMARRI, A. \& BATCHELOR, J.R. - HLA and hepatitis B infection. Lancet, 344: 1194-1195, 1994.

5. ALRIC, L.; FORT, M.; IZOPET, J. et al. - Genes of the major histocompatibility complex II influence the outcome of hepatitis C virus infection. Gastroenterology, 113: 16751681, 1997.

6. ANONYMOUS - Recommendations for prevention and control of hepatitis $\mathrm{C}$ virus (HCV) infection and HCV-related chronic disease. MMWR, 47: 1-39, 1998.

7. AWAD, M.R.; EL-GAMEL, A.; HASLETON, P. et al. - Genotypic variation in the transforming growth factor-beta 1 gene: association with transforming growth factorbeta 1 production, fibrotic lung disease and graft fibrosis after lung transplantation. Transplantation, 66: 1014-1020, 1998.

8. BAKER, S.J. \& REDDY, E.P. - Transducers of life and death: TNF receptor superfamily and associated proteins. Oncogene, 12: 1-9, 1996.

9. BARRETT, S.; RYAN, E. \& CROWE, J. - Association of the HLA-DRB $1 * 01$ allele with spontaneous viral clearance in an Irish cohort infected with hepatitis $\mathrm{C}$ virus via contaminated anti-D immunoglobulin. J. Hepat., 30: 979-983, 1999.

10. BATALLER, R.; GINES, P.; GORBIG, M.N. et al.- Angiotensin II induces contraction and is motogenic for culture human hepatic stellate cells. Antagonization by losartan and modulation by vasodilators [Abstract]. Hepatology, 28 (suppl.): 437A, 1998. 
11. BEDOSSA, P. \& PARADIS, V. - Transforming growth factor-beta (TGF-beta): a keyrole in liver fibrogenesis. J. Hepat., 22 (suppl. 2): 37-42, 1995

12. BELLAMY, R.; RUWENDE, C.; CORRAH, T. et al. - Variations in the NRAMP 1 gene and susceptibility to tuberculosis in West Africans. New Engl. J. Med., 338: 640644, 1998

13. BELLAMY, R.; RUWENDE, C.; CORRAH, T. et al.- Tuberculosis and chronic hepatitis $B$ virus infection in Africans and variation in the vitamin D receptor gene. J. infect. Dis., 179: 721-724, 1999.

14. BONKOVSKY, H.L.; BANNER, B.F. \& ROTHMAN, A.L. - Iron and chronic viral hepatitis. Hepatology, 25: 759-768, 1997.

15. CARRINGTON, M.; MARTI, D.; WADE, J. et al. - Microsatellite markers in complex disease: mapping disease associated regions within in the human major histocompatibility complex. In: GOLDSTEIN, D.B. \& SCHOTTERER, C., ed Microsatellites: evolution and applications. Oxford, Oxford University Press, 1999 p. 225-237.

16. CARRINGTON, M.; NELSON, G.W.; MARTIN, M.P. et al. - HLA and HIV-1: heterozygote advantage and B* 35-Cw* 04 disadvantage. Science, 283: 1748-1752, 1999

17. CONGIA, M.; CLEMENT, M.G.; DESSI, C. et al. - HLA class II genes in chronic hepatitis $\mathrm{C}$ virus infection and associated immunological disorders. Hepatology, 24: 1338-1341, 1996.

18. CRAMP, M.E.; CARUCCI, P.; UNDERHILL, J. et al. - Association between HLA class II genotype and spontaneous clearance of hepatitis B viraemia. J. Hepat., 29: $207-$ $213,1998$.

19. DENG, H.; LIU, R.; ELLMEIER, W. et al. - Identification of a major co-receptor for primary isolates of HIV-1. Nature (Lond.), 381: 661-666, 1996.

20. DIB, C.; FAURE, S.; FIZAMES, C. et al. - A comprehensive genetic map of the human genome based on 5,264 microsatellites. Nature (Lond.), 380: 152-154, 1996.

21. DOHERTY, P.C. \& ZINKERNAGEL, R.M. - Enhanced immunological surveillance in mice heterozygous at the H-2 gene complex. Nature (Lond.), 256: 50-52, 1975.

22. DONALDSON, P.T.; DOHERTY, D.G.; HAYLLAR, K.M. et al. - Susceptibility to autoimmune chronic active hepatitis: human leukocyte antigens DR4 and A1-B8DR3 are independent risk factors. Hepatology, 13: 701-706, 1991.

23. FANNING, L.; KENNY, E.; SHEEHAN, M. et al. - Viral load and clinicopathological features of chronic hepatitis $\mathrm{C}(1 \mathrm{~b})$ in a homogeneous patient population. Hepatology, 29: 904-906, 1999.

24. FANNING, L.J.; LEVIS, J.; KENNY-WALSH, E. et al. - Viral clearance in hepatitis C (1b) infection: relationship with human leukocyte antigen class II in a homogeneous population. Hepatology, 31: 1334-1337, 2000.

25. FEDER, J.N.; GNIRKE, A.; THOMAS, W. et al. - A novel MHC class I-like gene is mutated in patients with hereditary haemochromatosis. Nature Genet., 13: 399408, 1996

26. FUJISAWA, T.; IKEGAMI, H.; KAWAGUCHI, Y. et al. - Class I HLA is associated with age-at-onset of IDDM, while class II HLA confers susceptibility to IDDM Diabetologia, 38: 1493-1495, 1995.

27. GIBBONS, G.H.; PRATT, R.E. \& DZAU, V.J. - Vascular smooth muscle cell hypertrophy vs hyperplasia: autocrine transforming growth factor $\beta 1$ expression determines growth responses to angiotensin II. J. clin. Invest., 90: 456-461, 1992.

28. GIORDANO, M.; OEFNER, P.J.; UNDERHILL, P.A. et al. - Identification by denaturing high-performance liquid chromatography of numerous polymorphisms in a candidate region for multiple sclerosis susceptibility. Genomics, 56: 247-253, 1999.

29. GUIDOTTI, L.G.; ISHIKAWA, T.; HOBBS, M.V. et al. - Intracellular inactivation of the hepatitis B virus by cytotoxic T lymphocytes. Immunity, 4: 25-36, 1996.
30. HEZODE, C.; CAZENEUVE, C.; COUE, O. et al. - Hemochromatosis Cys 282 Tyr mutation and liver iron overload in patients with chronic active hepatitis $\mathrm{C}$. Hepatology, 27: 306, 1998.

31. HIGASHI, Y.; KAMIKAWAJI, N.; SUKO, H. \& ANDO, M. - Analysis of HLA alleles in Japanese patients with cirrhosis due to chronic hepatitis C. J. Gastroent. Hepat., 11: 241-246, 1996.

32. HOHLER, T.; GERKEN, G.; NOTGHI, A. et al. - MHC class II genes influence the susceptibility to chronic active hepatitis C. J. Hepat., 27: 259-264, 1997.

33. HOHLER, T.; GERKEN, G.; NOTGHI, A. et al. - HLA-DRB $1 * 1301$ and $* 1302$ protect against chronic hepatitis B. J. Hepat., 26: 503-507, 1997.

34. HOHLER, T.; KRUGER, A.; GERKEN, G. et al. - Tumor necrosis factor alpha promoter polymorphism at position -238 is associated with chronic active hepatitis $\mathrm{C}$ infection. J. med. Virol., 54: 173-177, 1998.

35. HOHLER, T.; KRUGER, A.; GERKEN, G. et al. - A tumor necrosis factor-alpha (TNFalpha) promoter polymorphism is associated with chronic hepatitis B infection. Clin exp. Immunol., 111: 579-582, 1998.

36. HUE, S.; CACOUB, P.; RENOU, C. et al. - Human leukocyte antigen class II alleles may contribute to the severity of hepatitis $\mathrm{C}$ virus-related liver disease. J. infect. Dis., 186: 106-109, 2002.

37. JIANG, Y.G.; WANG, Y.M.; LIU, T.H. \& LIU, J. - Association between HLA class II gene and susceptibility or resistance to chronic hepatitis B. Wld. J. Gastroent., 9: 2221-2225, 2003

38. KAZEMI-SHIRAZI, L.; DATZ, C.; MAIER-DOBERSBERGER, T. et al. - The relation of iron status and hemochromatosis gene mutations in patients with chronic hepatitis C. Gastroenterology, 116: 127-134, 1999.

39. KENNY-WALSH, E. - Clinical outcomes after hepatitis C infection from contaminated anti-D immune globulin. Irish Hepatology Research Group. New Engl. J. Med., 340: 1228-1233, 1999

40. KNODELL, R.G.; ISHAK, K.G.; BLACK, W.C. et al. - Formulation and application of a numerical scoring system for assessing histological activity in asymptomatic chronic active hepatitis. Hepatology, 1: 431-435, 1981.

41. KOZIEL, M.J.; DUDLEY, D; AFDHAL, N. et al. - HLA class I - restricted cytotoxic T lymphocytes specific for hepatitis $\mathrm{C}$ virus. Identification of multiple epitopes and characterization of patterns of cytokine release. J. clin. Invest., 96: 2311-2321, 1995

42. KUZUSHITA, N.; HAYASHI, N.; KATAYAMA, K. et al. - Increased frequency of HLA DR13 in hepatitis C virus carriers with persistently normal ALT levels. J. med. Virol. 48: $1-7,1996$

43. KUZUSHITA, N.; HAYASHI, N.; MORIBE, T. et al. - Influence of HLA haplotypes on the clinical courses of individuals infected with hepatitis $C$ virus. Hepatology, 27: 240-244, 1998.

44. LEE, W.M. - Hepatitis B virus infection. New Engl. J. Med., 337: 1733-1745, 1997.

45. LECHMANN, M.; SCHNEIDER, E.M.; GIERS, G. et al. - Increased frequency of the HLA-DR15 (B1*15011) allele in German patient with self-limited hepatitis C virus infection. Europ. J. clin. Invest., 29: 337-343, 1999.

46. LIN, T.M.; CHEN, C.J.; WU, M.M. et al. - Hepatitis B virus markers in Chinese twins Anticancer Res., 9: 737-741, 1989

47. LONG, K.Z. \& SANTOS, J.I. - Vitamins and the regulation of the immune response Pediat. infect. Dis., 18: 283-290, 1999.

48. MANGIA, A.; GENTILE, R.; CASCAVILLA, I. et al. - HLA class II favors clearance of HCV infection and progression of the chronic liver damage. J. Hepat., 30: 984-989, 1999. 
49. MARTINSON, J.J.; CHAPMAN, N.H.; REES, D.C.; LIU, Y.T. \& CLEGG, J.B. - Global distribution of the CCR5 gene 32-basepair deletion. Nature Genet., 16: 100-103, 1997.

50. McKIERNAN, S.M.; HAGAN, R.; CURRY, M. et al.. - Human leucocyte antigens related to disease outcome in hepatitis C [Abstract]. Hepatology, 28 (suppl.): 214A, 1998.

51. McKIERNAN, S.M.; HAGAN, R.; CURRY, M. et al. - The MHC is a major determinant of viral status but not fibrotic stage, in individuals infected with hepatitis C. Gastroenterology, 118: 1124-1130, 2000.

52. MINTON, E.J.; SMILLIE, D.; NEAL, K.R. et al. - Association between MHC class II alleles and clearance of circulating hepatitis C virus. J. infect. Dis., 178: 39-44, 1998.

53. MOTA, A.H.; FAINBOIM, H.; TERG, R. \& FAINBOIM, L. - Association of chronic active hepatitis and HLA B35 in patients with hepatitis B virus. Tissue Antigens, 30: $238-240,1987$

54. PEANO, G.; MENARDI, G.; PONZETTO, A. \& FENOGLIO, L.M. - HLA-DR5 antigen: a genetic factor influencing the outcome of hepatitis $\mathrm{C}$ virus infection? Arch. intern. Med., 154: 2733-2736, 1994.

55. POWELL, E.E.; EDWARDS-SMITH, C.J.; HAY, J.L. et al. - Host genetic factors influence disease progression in chronic hepatitis C. Hepatology, 31: 828-833, 2000.

56. POWER, J.P.; LAWLOR, E.; DAVIDSON, F. et al. - Hepatitis C viraemia in recipients of Irish intravenous anti-D immunoglobulin. Lancet, 344: 1166-1167, 1994.

57. POWER, J.P.; LAWLOR, E.; DAVIDSON, F. et al. - Molecular epidemiology of an outbreak of infection with hepatitis $\mathrm{C}$ virus in recipients of anti-D immunoglobulin. Lancet, 345: 1211-1213, 1995.

58. POYNARD, T.; BEDOSSA, P. \& OPOLON, P. - Nature history of liver fibrosis progression in patients with chronic hepatitis C. The OBSVIRC, METAVIR, CLINIVIR, and DOSVIRC groups. Lancet, 349: 825-832, 1997.

59. RACIOPPI, L.; RONCHESE, F.; SCHWARTZ, R.H. \& GERMAIN, R.N. - The molecular basis of class II MHC allelic control of T cell responses. J. Immunol., 147: 37183727, 1991.

60. RENOU, C.; HALFON, P.; POL, S. et al. - Histological features and HLA class II alleles in hepatitis $\mathrm{C}$ virus chronically infected patients with persistently normal alanine aminotransferase levels. Gut, 51: 585-590, 2002

61. SHERON, N.; LAU, J.; DANIELS, H. et al. - Increased production of tumour necrosis factor alpha in chronic hepatitis B virus infection. J. Hepat., 12: 241-245, 1991.

62. SMITH, B.C.; GORVE, J.; GUZAIL, M.A. et al. - Heterozygosity for hereditary hemochromatosis is associated with more fibrosis in chronic hepatitis C. Hepatology, 27: $1695-1699,1998$

63. STEEL, C.M.; LUDLAM, C.A.; BEATSON, D. et al. - HLA haplotype A1 B8 DR3 as a risk factor for HIV-related disease. Lancet, 1: 1185-1188, 1988

64. SUMMERFIELD, J.A.; RYDER, S.; SUMIYA, M. et al. - Mannose binding protein gene mutations associated with unusual and severe infection in adults. Lancet, 345: 886-889, 1995.

65. TEWS, B.; WILHELM, J.; SUMMERER, D. et al. - Application of the C4'alkylated deoxyribose primer system (CAPS) in allele-specific real-time PCR for increased selectivity in discrimination of single nucleotide sequence variants. Biol. Chem., 384: $1533-1541,2003$.

66. THIO, C.L; CARRINGTON, M.; MARTI, D. et al. - Class II HLA alleles and hepatitis B virus persistence in African Americans. J. infect. Dis., 179: 1004-1006, 1999.

67. THIO, C.L.; THOMAS, D.L. \& CARRINGTON, M. - Chronic viral hepatitis and the human genome. Hepatology, 31: 819-827, 2000.
68. THIO, C.L.; THOMAS, D.L.; GOEDERT, J.J. et al. - Racial differences in HLA class II associations with hepatitis C virus outcomes. J. infect. Dis., 184: 16-21, 2001.

69. THIO, C.L.; GAO, X.; GOEDERT, J.J. et al. - HLA-Cw*04 and hepatitis C virus persistence. J. Virol., 76: 4792-4797, 2002.

70. THIO, C.L.; THOMAS, D.L.; KARACKI, P. et al. - Comprehensive analysis of class I and class II HLA antigens and chronic hepatitis B virus infection. J. Virol., 77: 12083- 12087, 2003

71. THOMAS, H.C.; FOSTER, G.R.; SUMIYA, M. et al. - Mutation of gene of mannosebinding protein associated with chronic hepatitis B viral infection. Lancet, 348: 1417-1419, 1996.

72. THURSZ, M.R.; KWIATKOWSKI, D.; ALLSOPP, C.E.M. et al. - Association between an MHC class II allele and clearance of hepatitis B virus in the Gambia. New Engl. J. Med., 332: 1065-1069, 1995.

73. TIBBS, C.; DONALDSON, P.; UNDERHILL, J.A. et al. - Evidence that the HLA DQA $1 * 03$ allele confers protection from chronic $\mathrm{HCV}$-infection in Northern European Caucasoids. Hepatology, 24: 1342-1345, 1996.

74. TILLMANN, H.L.; CHEN, D.F.; TRAUTWEIN, C. et al. - Low frequency of HLADRB1*11 in hepatitis $C$ virus induced end stage liver disease. Gut, 48: 714-718, 2001

75. TROWSDALE, J. - Molecular genetics of HLA class I and class II regions. In: BROWNING, M. \& McMICHAEL, A., ed. HLA and MHC: genes molecules and function. Oxford, Bios Scientific, 1996. p. 23-37.

76. TURNER, D.M.; WILLIAMS, D.M.; SANKARAN, D. et al. - An investigation of polymorphism in the interleukin-10 gene promoter. Europ. J. Immunogenet., 24: $1-8,1997$

77. VAN HATTUM, J.; SCHREUDER, G.M. \& SCHALM, S.W. - HLA antigens in patients with various courses after hepatitis B virus infection. Hepatology, 7: 11-14, 1987.

78. VERDON, R.; POL, S.; LANDAIS, P. et al. - Absence of association between HLA antigens and chronicity of viral hepatitis in haemodialyzed patients. J. Hepat., 21: 388-393, 1994

79. VILLANO, S.A.; VLAHOV, D.; NELSON, K.E. et al. - Persistence of viremia and the importance of long-term follow-up after acute hepatitis C infection. Hepatology, 29: 908-914, 1999.

80. WANG, S.C.; OHATA, M.; SCHRUM, L.; RIPPE, R.A. \& TSUKAMOTO, H. Expression of interleukin-10 by in vitro and in vivo activated hepatic stellate cells. J. biol. Chem., 273: 302-308, 1998

81. WILSON, A.G.; DE VRIES, N.; PACIOT, F. et al. - An allelic polymorphism within the human tumor necrosis factor alpha promoter region is strongly associated with HLAA1, B8 and DR3 alleles. J. exp. Med., 177: 557-560, 1993.

82. WILSON, A.G.; DI GIOVINE, F.S.; BLAKEMORE, A.I. \& DUFF, G.W. - Single base polymorphism in the human tumour necrosis factor alpha (TNF-alpha) gene detectable by Ncol restriction of PCR product. Hum. Molec. Genet., 1: 353, 1992.

83. YENIGUN, A. \& DURUPINAR, B. - Decreased frequency of the HLA-DRB1*11 allele in patients with chronic hepatitis C virus infection. J. Virol., 76: 1787-1789, 2002.

84. YOSHIZAWA, K.; OTA, M.; SAITO, S. et al. - Long-term follow-up of hepatitis C virus infection: HLA class II loci influences the natural history of the disease. Tissue Antigens, 61: 159-165, 2003

85. ZAVAGLIA, C.; BORTOLON, C.; FERRIOLI, G et al. - HLA typing in chronic type B, D and C hepatitis. J. Hepat., 24: 658-665, 1996.

Received: 14 November 2003

Accepted: 3 May 2004 